\title{
Risk Factors for Cardiovascular Disease: Evidence from Studies
}

\author{
Leonardo Roever* and Resende ES
}

Department of Clinical Research, Federal University of Uberlândia, Brazil

${ }^{*}$ Corresponding author: Leonardo S. Roever-Borges, Av. Para, 1720 - Bairro Umuarama, Uberlândia - MG - CEP 38400-902, Brazil, Tel: +553488039878; E-mail: leonardoroever@hotmail.com

Received February 17, 2014; Accepted February 20, 2015; Published February 23, 2015

Copyright: (c) 2015 Roever L, et al. This is an open-access article distributed under the terms of the Creative Commons Attribution License, which permits unrestricted use, distribution, and reproduction in any medium, provided the original author and source are credited.

\section{Editorial}

Cardiovascular disease (CVD) is the leading cause of morbidity and mortality in the world $[1,2]$. Risk factors such as hypertension, metabolic syndrome, cigarette smoking, diabetes mellitus, elevated glucose and cholesterol levels, and obesity or being overweight are the top causes of death globally [3,4]. The Emerging Risk Factors Collaboration incorporating 160,309 study participants demonstrated the independent predictive value of C-reactive protein (CRP) for coronary heart disease (CHD) and stroke, the clinical utility of CRP and fibrinogen in CVD risk prediction, and the limited role of adding the novel lipid markers apolipoprotein A-I, lipoprotein (a), apolipoprotein B, and lipoprotein-associated phospholipase A2 to traditional lipid measures [5-7].

The MESA study demonstrate ethnic differences in coronary artery calcium and its association with CHD events, participants with metabolic syndrome or diabetes, the risk of CHD events varied 10 -fold across levels of coronary calcium, showing that the risk of CHD is low if no calcium is present, challenging the concept of diabetes as a $\mathrm{CHD}$ risk equivalent [8-11].

The Jackson Heart Study provided valuable information on genetic and lifestyle determinants of metabolic syndrome, cardiovascular risk factors, novel biomarkers and prediction of CVD events. Adiponectin was directly associated with incident stroke in women, but not in men and not with CHD in either sex, whereas leptin was not associated with either CHD or stroke $[12,13]$.

The Cardiovascular Health Study reported on age-related trends in cardiovascular morbidity and physical functioning, risk factors associated with mortality in elderly adults, and associations between isolated systolic hypertension and subclinical CVD [14-16].

The Strong Heart Study reports the associations between insulin resistance, metabolic syndrome, and CVD [17]. The CARDIA study reports the relationship between weight change above the age of 15 years and changes in CHD risk factors, and the ethnic differences in the incidence of heart failure among young adults [18-19]. The ARIC study described risk factor associations with carotid atherosclerosis [20-22].

The PROCAM study reports the prevalence and prognosis associated with important CHD risk factors and development of a risk prediction score for CHD [23,24]. The INTERHEART study describes nine risk factors (apolipoprotein B, apolipoprotein A-I, current smoking, diabetes, hypertension, or abdominal obesity, psychosocial index, lack of exercise, and excessive alcohol intake) were associated with acute myocardial infarcted (AMI), with risks consistent across all regions, ethnic groups, and men and women worldwide [25,26].

The PURE study describe a widespread low prevalence of healthy lifestyle behaviours across countries of all levels of income, with a particularly low prevalence of these behaviours, and a very low rate of cardioprotective drug use in secondary prevention, in low-income countries $[27,28]$. The MONICA project showing that the rate of smoking generally decreased in men, but increased in women, the rate of systolic blood pressure and cholesterol levels decreased in both sexes, but that BMI increased significantly in over half of the populations studied. This study shows the important association between serum cholesterol and CHD $[29,30]$.

The Ni-Hon-San study showed higher cholesterol levels and higher CHD mortality than men who remained in Japan [31,32]. The Whitehall studies show inverse associations between fair and respectful treatment at work and CHD and roles of genetic and nongenetic factors in the prediction of type 2 diabetes $[33,34]$.

The Framingham Heart Study demonstrated the association blood pressure and congestive heart failure, abdominal adiposity and metabolic disorders, diabetes duration on coronary heart disease mortality [35-37]. The Uberlândia Heart Study reports the association of abdominal adiposity and metabolic disorders [38-42].

The sleep time and snoring have been associated with CVD risk in Western populations. In a study aimed to address the relation between sleep duration, snoring frequency and risk of (AMI) in China population. Snoring frequency, including as much as every day and 3-5 times per week, was positively associated with AMI risk and less sleep duration was associated with risk of AMI [38].

Cardiovascular risk factors including metabolic syndrome, hypertension, cigarette smoking, high blood glucose, physical inactivity, obesity, and elevated cholesterol levels are the leading causes of death worldwide. The identification of risk factors provides new opportunities for developing more effective approaches for preventing and treatment of cardiovascular disease.

\section{References}

1. Mozaffarian D, Benjamin EJ, Go AS, Arnett DK, Blaha MJ, et al. (2015) Heart disease and stroke statistics-2015 update: a report from the american heart association. Circulation 131: e29-29e322.

2. Murray CJ, Vos T, Lozano R, Naghavi M, Flaxman AD, et al. (2012) Disability-adjusted life years (DALYs) for 291 diseases and injuries in 21 regions, 1990-2010: a systematic analysis for the Global Burden of Disease Study 2010. Lancet 380: 2197-2223.

3. Wong ND (2014) Epidemiological studies of CHD and the evolution of preventive cardiology. Nat Rev Cardiol 11: 276-289.

4. Lozano R, Naghavi M, Foreman K, Lim S, Shibuya K, et al. (2012) Global and regional mortality from 235 causes of death for 20 age groups in 1990 and 2010: a systematic analysis for the Global Burden of Disease Study 2010. Lancet. 380: 2095-2128.

5. Emerging Risk Factors Collaboration, Kaptoge S, Di Angelantonio E, Pennells L, Wood AM, et al. (2012) C-reactive protein, fibrinogen, and cardiovascular disease prediction. N Engl J Med 367: 1310-1320. 
6. Emerging Risk Factors Collaboration, Di Angelantonio E, Gao P, Pennells L, Kaptoge S, et al. (2012) Lipid-related markers and cardiovascular disease prediction. JAMA 307: 2499-2506.

7. Emerging Risk Factors Collaboration, Kaptoge S, Di Angelantonio E, Lowe G, Pepys MB, et al. (2010) C-reactive protein concentration and risk of coronary heart disease, stroke, and mortality: an individual participant meta-analysis. Lancet 375: 132-140.

8. Polonsky TS, McClelland RL, Jorgensen NW, Bild DE, Burke GL, et al. (2010) Coronary artery calcium score and risk classification for coronary heart disease prediction. JAMA 303: 1610-1616.

9. Detrano R, Guerci AD, Carr JJ, Bild DE, Burke G, et al. (2008) Coronary calcium as a predictor of coronary events in four racial or ethnic groups. N Engl J Med 358: 1336-1345.

10. Yeboah J, McClelland RL, Polonsky TS, Burke GL, Sibley CT, et al. (2012) Comparison of novel risk markers for improvement in cardiovascular risk assessment in intermediate-risk individuals. JAMA 308: 788-795.

11. Malik S, Budoff MJ, Katz R, Blumenthal RS, Bertoni AG, et al. (2011) Impact of subclinical atherosclerosis on cardiovascular disease events in individuals with metabolic syndrome and diabetes: the multi-ethnic study of atherosclerosis. Diabetes Care 34: 2285-2290.

12. Liu J, Fox CS, Hickson D, Sarpong D, Ekunwe L, et al. (2010) Pericardial adipose tissue, atherosclerosis, and cardiovascular disease risk factors: the Jackson heart study. Diabetes Care 33: 1635-1639.

13. Bidulescu A, Liu J, Chen Z, Hickson DA, Musani SK, et al. (2013) Associations of adiponectin and leptin with incident coronary heart disease and ischemic stroke in African Americans: the Jackson Heart Study. Front. Public Health 1: 16.

14. Bild DE, Fitzpatrick A, Fried LP, Wong ND, Haan MN, et al. (1993) Agerelated trends in cardiovascular morbidity and physical functioning in the elderly: the Cardiovascular Health Study. J Am Geriatr Soc 41: 1047-1056.

15. Fried LP, Kronmal RA, Newman AB, Bild DE, Mittelmark MB, et al. (1998) Risk factors for 5-year mortality in older adults: the Cardiovascular Health Study. JAMA 279: 585-592.

16. Psaty BM, Furberg CD, Kuller LH, Borhani NO, Rautaharju PM, et al. (1992) Isolated systolic hypertension and subclinical cardiovascular disease in the elderly. Initial findings from the Cardiovascular Health Study. JAMA 268: 1287-1291.

17. Resnick HE, Jones K, Ruotolo G, Jain AK, Henderson J, et al. (2003) Insulin resistance, the metabolic syndrome, and risk of incident cardiovascular disease in nondiabetic American Indians: the Strong Heart Study. Diabetes Care 26: 861-867.

18. Truesdale KP, Stevens J, Lewis CE, Schreiner PJ, Loria CM, et al. (2006) Changes in risk factors for cardiovascular disease by baseline weight status in young adults who maintain or gain weight over 15 years: the CARDIA study. Int J Obes (Lond) 30: 1397-1407.

19. Bibbins-Domingo K, Pletcher MJ, Lin F, Vittinghoff E, Gardin JM, et al. (2009) Racial differences in incident heart failure among young adults. N Engl J Med 360: 1179-1190.

20. Heiss G, Sharrett AR, Barnes R, Chambless LE, Szklo M, et al. (1991) Carotid atherosclerosis measured by B-mode ultrasound in populations: associations with cardiovascular risk factors in the ARIC study. Am J Epidemiol 134: 250-256

21. Nambi V, Chambless L, Folsom AR, He M, Hu Y, et al. (2010) Carotid intima-media thickness and presence or absence of plaque improves prediction of coronary heart disease risk: the ARIC (Atherosclerosis Risk In Communities) study. J Am Coll Cardiol 55: 1600-1607.

22. Nambi V, Boerwinkle E, Lawson K, Brautbar A, Chambless L, et al. (2012) The 9p21 genetic variant is additive to carotid intima media thickness and plaque in improving coronary heart disease risk $\approx$ prediction in white participants of the Atherosclerosis Risk in Communities (ARIC) Study. Atherosclerosis 222: 135-137.

23. Assmann G, Cullen P, Schulte H (2002) Simple scoring scheme for calculating the risk of acute coronary events based on the 10-year followup of the prospective cardiovascular Münster (PROCAM) study. Circulation 105: 310-315.
24. Hense HW, Schulte H, Löwel H, Assmann G, Keil U (2003) Framingham risk function overestimates risk of coronary heart disease in men and women from Germany-results from the MONICA Augsburg and the PROCAM cohorts. Eur. Heart J 24: 937-945.

25. Yusuf S, Hawken S, Ounpuu S, Dans T, Avezum A, et al. (2004) Effect of potentially modifiable risk factors associated with myocardial infarction in 52 countries (the INTERHEART study): case-control study. Lancet 364: 937-952.

26. Rosengren A, Hawken S, Ounpuu S, Sliwa K, Zubaid M, et al. (2004) Association of psychosocial risk factors with risk of acute myocardial infarction in ,119 cases and 13,648 controls from 52 countries (the INTERHEART study): case-control study. Lancet 364: 953-962.

27. Teo K, Lear S, Islam S, Mony P, Dehghan M, et al. (2013) Prevalence of a healthy lifestyle among individuals with cardiovascular disease in high-, middle-, and low-income countries: the Prospective Urban Rural Epidemiology (PURE) study. JAMA 309: 1613-1621.

28. Yusuf S, Islam S, Chow CK, Rangarajan S, Dagenais G, et al. (2011) Prospective Urban Rural Epidemiology (PURE) Study Investigators. Use of secondary prevention drugs for cardiovascular disease in the community in high-income, middle-income, and low-income countries (the PURE Study): a prospective epidemiological survey. Lancet 378: 1231-1243.

29. Evans A, Tolonen H, Hense HW, Ferrario M, Sans S, et al. (2001) Trends in coronary risk factors in the WHO MONICA project. Int J Epidemiol 30 Suppl 1: S35-40.

30. Leupker RV (2012) WHO MONICA Project: what have we learned and where to go from here? Public Health Reviews 33: 373-396.

31. Worth RM, Kato H, Rhoads GG, Kagan K, Syme SL (1975) Epidemiologic studies for coronary heart disease and stroke in Japanese men living in Japan, Hawaii, and California: mortality. Am. J. Epidemiol 102: 481-490.

32. Sekikawa A, Horiuchi BY, Edmundowicz D, Ueshima H, Curb JD, et al. (2003) A "natural experiment" in cardiovascular epidemiology in the early 21 st century. Heart 89: 255-257.

33. Kivimäki M, Ferrie JE, Brunner E, Head J, Shipley MJ, et al. (2005) Justice at work and reduced risk of coronary heart disease among employees: the Whitehall II Study. Arch Intern Med 165: 2245-2251.

34. Talmud PJ, Hingorani AD, Cooper JA, Marmot MG, Brunner EJ, et al. (2010) Utility of genetic and non-genetic risk factors in prediction of type 2 diabetes: Whitehall II prospective cohort study. BMJ 340: b4838.

35. Haider AW, Larson MG, Franklin SS, Levy D; Framingham Heart Study (2003) Systolic blood pressure, diastolic blood pressure, and pulse pressure as predictors of risk for congestive heart failure in the Framingham Heart Study. Ann Intern Med 138: 10-16.

36. Fox CS, Sullivan L, D'Agostino RB Sr, Wilson PW; Framingham Heart Study (2004) The significant effect of diabetes duration on coronary heart disease mortality: the Framingham Heart Study. Diabetes Care 27: 704-708.

37. Fox CS, Massaro JM, Hoffmann U, Pou KM, Maurovich-Horvat P, et al. (2007) Abdominal visceral and subcutaneous adipose tissue compartments: association with metabolic risk factors in the Framingham Heart Study. Circulation 116: 39-48.

38. Xie D, Li W, Wang Y, Gu H, Teo K, et al. (2014) Sleep duration, snoring habits and risk of acute myocardial infarction in China population: results of the INTERHEART study. BMC Public Health 14: 531.

39. Roever L, Resende ES, Diniz ALD, Resende LH, Penha-Silva N, et al. (2012) Role of peri-renal fat in association with risk factors for atherosclerosis: World Congress of Cardiology 2012, Dubai, United Arab Emirates. Circulation.

40. Roever L, Resende ES, Diniz ALD, Resende LH, Penha-Silva N, et al. (2012) Can the peri-renal fat be considered as diagnostic criterion for metabolic syndrome?. In: World Congress of Cardiology(WCC), Dubai, United Arab Emirates. Circulation.

41. Roever L, Resende ES, Diniz ALD, Resende LH, Penha-Silva N, et al. (2012) Thickness of visceral fat and risk markers of atherosclerosis. In: 
Citation: $\quad$ Roever L, Resende ES (2015) Risk Factors for Cardiovascular Disease: Evidence from Studies. J Cardiovasc Dis Diagn 3: e107. doi: $10.4172 / 2329-9517.1000 \mathrm{e} 107$

Page 3 of 3

World Congress of Cardiology(WCC), Dubai, United Arab Emirates. Circulation.

42. Roever L, Resende ES, Penha-Silva N, Roever-Borges AS, Filho AC, et al (2014) visceral fat and differences between risk factors and coronary syndromes. 82nd Congress of the European Atherosclerosis Society (EAS 2014), Madrid. Atherosclerosis 235: 192-193. 